See discussions, stats, and author profiles for this publication at: https://www.researchgate.net/publication/254321424

\title{
Postcolonialism, postsocialism and the anthropology of east-central Europe
}

Article in Journal of Postcolonial Writing · May 2012

DOI: 10.1080/17449855.2012.658246

\section{CITATIONS}

25

1 author:

(6)

na Cervinkova

Dolnośląska Szkoła Wyższa

14 PUBLICATIONS 76 CITATIONS

SEE PROFILE

Some of the authors of this publication are also working on these related projects:

Project $\quad$ European Doctorate in Teacher Education (EDiTE) View project

Project „Proměny české a polské pohraniční Školy poskytující povinné vzdělávání po r. 1989. Komparativní studie“ (7 AMB13PL021) View project
READS

727 
This article was downloaded by: [Hana Cervinkova]

On: 25 April 2012, At: 01:44

Publisher: Routledge

Informa Ltd Registered in England and Wales Registered Number: 1072954 Registered

office: Mortimer House, 37-41 Mortimer Street, London W1T 3J H, UK

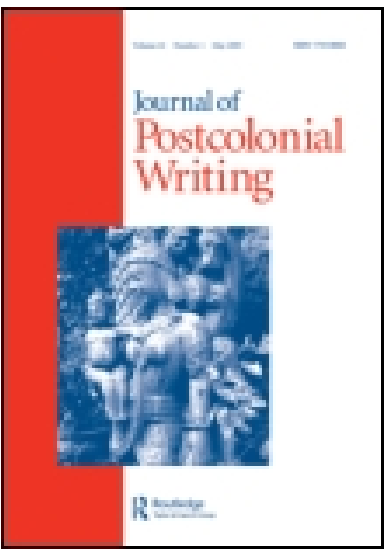

\section{J ournal of Postcolonial Writing}

Publication details, including instructions for authors and subscription information:

http:// www.tandfonline.com/loi/ rjpw20

\section{Postcolonialism, postsocialism and the anthropology of east-central Europe}

Hana Cervinkova ${ }^{a}$

a University of Lower Silesia, Poland

Available online: 20 Mar 2012

To cite this article: Hana Cervinkova (2012): Postcolonialism, postsocialism and the anthropology of east-central Europe, J ournal of Postcolonial Writing, 48:2, 155-163

To link to this article: http:// dx. doi.org/ 10.1080/17449855.2012.658246

\section{PLEASE SCROLL DOWN FOR ARTICLE}

Full terms and conditions of use: http://www.tandfonline.com/page/terms-andconditions

This article may be used for research, teaching, and private study purposes. Any substantial or systematic reproduction, redistribution, reselling, loan, sub-licensing, systematic supply, or distribution in any form to anyone is expressly forbidden.

The publisher does not give any warranty express or implied or make any representation that the contents will be complete or accurate or up to date. The accuracy of any instructions, formulae, and drug doses should be independently verified with primary sources. The publisher shall not be liable for any loss, actions, claims, proceedings, demand, or costs or damages whatsoever or howsoever caused arising directly or indirectly in connection with or arising out of the use of this material. 


\title{
Postcolonialism, postsocialism and the anthropology of east-central Europe
}

\author{
Hana Cervinkova* \\ University of Lower Silesia, Poland
}

\begin{abstract}
In this paper, I consider the issue of postcolonialism and postsocialism from the perspective of the discipline of anthropology. I argue that the recent efforts of anthropologists at bringing postcolonialism and postsocialism into dialogue can help us to develop a fresh conceptual framing of ethnographic problems and can play a positive role in the dismantling of the historically generated and geographically bounded divisions that have determined scholarly approaches to analysing peoples' experiences in different parts of the globe. I insist, however, on what I consider to be a key epistemological divergence between the two concepts. While postcolonialism was born as a project of indigenous epistemological critique of the persistence of colonialism in the postcolonial present with emancipatory/liberatory implications, postsocialism was developed as an analytical tool by western scholars to analyse the former societies of the Communist bloc. This hegemonic epistemology of postsocialism makes it a very different concept from postcolonialism and raises questions concerning its usefulness as an intellectually empowering tool for scholars in challenging local inequities arising from the effects of global capitalism. In order to illustrate this limitation, I review the recent disciplinary debate on the politics of knowledge production between native and western anthropologists of postsocialism.
\end{abstract}

Keywords: postsocialism; postcolonialism; anthropology; epistemology; global capitalism

\section{Introduction}

In this article, I consider the emergent efforts of social and cultural anthropologists to bring the categories of postcolonialism and postsocialism into dialogue and develop fresh conceptual framing of the problems we address in our ethnographic observations and writing. I will argue that such "thinking between" postcolonialism and postsocialism (Chari and Verdery) can play a role in the dismantling of the historically generated and geographically bounded divisions that have determined scholarly approaches to analysing peoples' experiences in different parts of the world. The understanding of our postsocialist/postcommunist condition through a postcolonial lens holds a promise for indigenous scholarship in east-central Europe. I will, however, insist on a lasting and crucial point of epistemological divergence between postsocialism and postcolonialism, which continues to inform our efforts and which should be taken into consideration when these categories of thought are used to analyse postcolonial/postsocialist societies. In order to illustrate this limitation, I will review a recent disciplinary debate between native and western

\footnotetext{
*Email: hana@post.pl
} 
anthropologists of postsocialism which reveals the very different politics of knowledge production that have accompanied the development of postcolonial and postsocialist scholarship. I am hoping that my discussion will help illuminate one of the questions posed by the editors of this volume, who observe that while the overlap of postcommunism and postcolonialism has been a much debated topic in east-central Europe, it has been rarely addressed in the postcolonial scholarly arena.

\section{Postsocialism and anthropology of east-central Europe}

Instead of the term postcommunism, I choose to use the word postsocialism, a discursive category adopted by western and eventually also native anthropologists to describe the lived realities of peoples and communities after the fall of communist regimes in east-central Europe (Berdahl, Bunzl, and Lampland; Burawoy; Burawoy and Verdery; Cervinkova; Hann; Kürti and Skalník; Verdery). Postsocialism replaced earlier terms, such as "transition", which encouraged an analysis of the former socialist societies in accordance with the development and modernization theories (Tulbure 3-4; Wolfe 197-98) that had been commonly applied to them during the Cold War. These mostly US-based academic approaches relied on the geographically based intellectual division of the globe into three worlds after 1950: "the first world" (the west) - studied primarily by the "theoretical" social sciences (economics, political science, sociology), "the second world" (most of the totalitarian socialist states) - studied by so-called area studies (Soviet studies/Sovietology), and "the third world" (most of the former colonies) - mostly left to anthropology (Tulbure). The anthropology of east-central Europe was able to transgress the second/third world disciplinary boundary and developed as a subfield of Soviet Studies. Its real boom came after 1989 when state borders opened and east-central Europe became a laboratory for the study of the processes of change that were underway in this formerly difficult to access part of the world.

Postsocialism was used by US and western European anthropologists first as a temporal term denoting the period after the socialist system (defined by state-controlled ownership of the most important means of production and the political monopoly of the Communist Party) had been dismantled, and replaced by democratizing systems. Postsocialism was defined as a period characterized primarily by the privatization of property and the pluralization of political power, and western anthropologists (building on the tradition of Cold War Soviet studies) mostly focused on analysing issues concerning the state, economics and politics: "The Cold War was responsible for the almost obsessive interest in the socialist state and the political-economic processes constituting it, as well as for the more superficial understanding of social meanings, personal experiences, and values" (Tulbure 3). In the second half of the 1990s, however, this traditional focus came under criticism and anthropologists started paying more attention to the micro-level changes that were taking place in people's lives. At this time, postsocialism came to denote

a particular style of doing ethnographic work. This ethnographic style was more attentive to meanings, values and local experiences (focusing on themes like memory, consumption, identity, nationalism, etc.) often in reaction to the political-economic approaches that characterized previous scholarship on socialism. (Tulbure 4)

Postsocialism as a western anthropologists' area and problematic has thus emerged from the collapse of the socialist political regime that "forced scholars of socialism to seek out new paradigms" (Chari and Verdery 10). 


\section{Postsocialism as orientalism}

Even though the term "postsocialism" was developed by western (North American and western European) anthropologists who studied east-central Europe, it has become generally accepted by east-central European scholars. Some Central European scholars, however, questioned the prevalence of western postsocialist scholarship and engaged in a disciplinary debate with their western colleagues about the politics of knowledge production in the anthropology of east-central Europe. The Czech anthropologist Petr Skalník has been one of the most active critics of the dominance of postsocialism, claiming openly that it is a mistaken concept because it leads us to believe that socialism really existed in the countries dominated in the past by the Communist Party. Skalník argues instead for communism/postcommunism as indigenous terms, because they more accurately describe the situation of those east-central European states which shared the history of the political hegemony of the Communist Party. Skalník has also called attention to the dominance of western conceptual models in the anthropology of east-central Europe and has worked actively to promote indigenous anthropological scholarship abroad. However, it is rather an ironic proof of his claims about the western-dominated politics of knowledge production that when he and the Hungarian anthropologist László Kürti finally published their edited book of ethnographies written by native anthropologists from east-central Europe in a major western publishing house, they had to change its original title from Postcommunist Europe to Postsocialist Europe.

An illustrative debate between native and western anthropologists of postsocialism was spurred by an article by the Polish anthropologist Michał Buchowski. In "Hierarchies of Knowledge in Central-Eastern European Anthropology", Buchowski argues that the anthropology of east-central Europe has been dominated by western scholarship and western-defined scholarly paradigms. Buchowski observes that, in their analyses, western anthropologists rarely refer to local ethnographies or theories, and that they work in "the pattern of one-sided theoretical input and confidence shown virtually only to western scholars" (7). In addition, native anthropologists' work has been rarely published by major international publishers and their work remains usually outside the "exclusive club" of authors who are invited to publish collective and edited works on postsocialist cultures and societies of east-central Europe. Buchowski charges his western colleagues with orientalizing tendencies, but he also looks critically at indigenous anthropological production in order to identify reasons for the west's scholarly hegemony. He divides local anthropological and ethnographic production into three major categories: (1) On the one hand, he argues, there are those anthropologists who have accepted western theoretical ideas and who separate themselves from the traditional Volkskundist ethnology. These theoreticians do not carry out fieldwork research and they publish exclusively conceptual works that lead "to an understanding of anthropology as a purely theoretical, almost philosophical enterprise" (9). (2) On the other hand, there are those who continue in the local Volkskundist tradition regardless of emergent theories. (3) Finally, there are those local scholars who apply general anthropological theories to local phenomena and events, without reference to non-native scholarship. In general, local anthropological scholarship, Buchowski claims, suffers from the twin condition plaguing many "minor cultures" - on the one hand an "inferiority complex" (a feeling that worthwhile concepts cannot be produced at the periphery) and, on the other, a localized "superiority complex" (only "we" can know best about "ourselves"). As a result, Buchowski critically observes, "in many respects, both in the past and today, 'we' anthropologists from CEE [Central Eastern Europe] have not produced the ideas that could attract general 
anthropological attention, although fifteen years already passed since 1989" (13). He concludes with a wishful note that by combining ethnographically and theoretically strong scholarship, indigenous anthropologists "will ultimately create a well established field of scholarship similar to postcolonial studies exercised by indigenous authors" (13).

The relevance of Buchowski's critical remarks was revealed in a response to his article written by Chris Hann, one of the leading British scholars of postsocialism. While Hann acknowledges the existence of the "hierarchies of knowledge" proposed by Buchowski, he resolutely denies that western anthropologists play a role in the orientalization of east-central Europe and of local scholarship, claiming that the domination of western scholarship is simply due to its superior quality: "If [Buchowski] and other 'local scholars' wish to be as widely read as some of the outsiders who write about CEE, then they need to put in the field time and write monographs of equivalent depth and sophistication" (195). Hann's response contains patronizing advice to east-central European anthropologists on how to improve their work, including such recommendations as "please try to arrange for [English language] editing by a native speaker" (194) or "CEE anthropologists might take advantage of postsocialist freedoms to embark on anthropological projects outside their home countries" (196). In his reply to Hann in the same issue, Buchowski critiques Hahn's position of superiority, pointing out the fissures in the presumed flawlessness of western anthropological production: "I, in turn, have a plea to foreign scholars who adorn their texts with words and phrases in local vernaculars: please try to arrange to have them reviewed by a [sic] native speakers, because frequently, they are rendered incorrectly" (198). Buchowski also stresses that while his goal was to point out the existence of the conceptual divide between western and central-east European anthropological production and look for possibilities of convergence between these theoretical and methodological traditions, for Hahn "convergence means adjustment of others to his own standards". Perhaps, he says, "Professor Hahn needs to tell us quite simply: how much homework do we CEEans still have to do before we become "us'?" (200). The conversation between these two leading anthropologists illustrates some of the ways in which versions of orientalism continue to operate in both western and east-central European epistemologies.

Said dates the origins of orientalism back to the late 18th century and defines it as the interplay of three interdependent meanings as (1) an academic study of the Orient (spanning many disciplines); (2) a more general style of thought based upon an ontological and epistemological distinction made between "the Orient" and "the Occident"; (3) a western style for dominating, restructuring and having authority over the Orient (2-3). Said's critical concept of orientalism as a hegemonic practice of othering has been imaginatively used by scholars analysing east-central Europe. Most notably, Larry Wolff wrote about eastern Europe as a product of the culturally hegemonic process of eastern Europe's orientalization during the Enlightenment, which successfully divided Europe into two distinct parts. He argues that this cultural and ideological divide was necessary for the construction of "Europe" as chiefly "western Europe", later becoming the blueprint for drawing the political Cold War frontier with the Iron Curtain. But while the Iron Curtain was dismantled with the fall of the communist regimes in east-central Europe, and despite the ongoing processes of European integration, the east/west academic anthropological debate is an example that the ideological and cultural boundaries between the west and east continue to last.

The debate between western and central European anthropologists points to the difficulties of dismantling western epistemological hegemony in the academic discourse and practices on both sides of the no-longer-existing east/west frontier. So why is it that we 
as east-central European anthropologists rely on western paradigms and seem incapable of developing original concepts that would be as intellectually powerful and empowering as postcolonial theories? Why is it that students of postsocialism look to postcolonialism for inspiration, but postcolonial scholarship does not seem to be too interested in what studies of postsocialism have to contribute? I would like to suggest that a minimal explanation of this imbalance is the differential epistemological provenance of postsocialist and postcolonial theories that continues to play a major part in their contemporary relevance.

Postsocialism, as its epistemology within the anthropology of east-central Europe illustrates, is essentially a western concept that grew out of the Cold War tradition of studies of socialism in the Soviet Empire by western scholars. Its absorption by indigenous scholars in central and eastern Europe was due to the complex workings of the processes of cultural hegemony following the political, military, economic and ideological defeat of the communist regimes in the former Soviet Bloc. The Cold War had its victors and losers; communism had lost, and the defeat of its political regime shifted into the historical denigration of peoples' work and life worlds under communism. Caught in the tumult of changes that condemned the past and celebrated the future, we bought postsocialism together with neo-liberalism and other western products. Seen from this local critical perspective, postsocialism is an orientalizing concept through which western anthropologists constructed postcommunist Europe.

Unlike postsocialism, postcolonial theory is a result of an indigenous project of critique that emerged several decades after the anti-colonial struggles had celebrated victory in the third world. Postcolonial thinking, which originated in the 1980s in the fields of literary and cultural studies, critiqued the continued discursive and practical consequences of colonial projects (Said 1978; Spivak 1987; Bhabha 1990, 1994; Mbembe 2001). But despite its critical perspective on the lasting impact of the colonial heritage on postcolonial lifeworlds, postcolonialism, which follows up on a political victory over colonialism, is an indigenous epistemological critique that contains overt political and cultural emancipatory aspirations. Postcolonial theory is an intellectual project of epistemologically inspired liberation, while postsocialism is a project of epistemological dominance and subjugation; postcolonial scholars have not as often looked toward postsocialism, among other things, because the latter is a hegemonic analytical tool that lacks the empowering qualities of postcolonial scholarship.

\section{Thinking through postsocialism/postcolonialism in anthropology}

While I believe that it is postcolonial theory that has much more to offer to the rethinking of east-central European realities after communism than postsocialism can contribute to postcolonial thought, recent anthropological writing shows that thinking through their relations can help erode binary oppositions that continue to limit our conceptual thinking about the world. I would therefore like to conclude this article with reviewing some of these attempts by anthropologists to bring postsocialism and postcolonialism together. Sharad Chari and Katherine Verdery, for example, argue that, despite serious differences between postsocialism and postcolonialism, both concepts "signify the complex results of the abrupt changes forced on those who underwent them: that is, becoming something other than socialist or other than colonized" and they share broad areas of similarity (11). They identify three areas in which "thinking between the posts can be useful for ethnographic and historical analysis of societies in the shadows of empires, whether capitalist or socialist" (12). 
The first area of complementarity is in rethinking the concept of empire. Chari and Verdery argue against a narrow view of empire based primarily on political incorporation and posit, instead, a definition that includes

such imperial innovations as the US government's neoliberalization of war through military contractors like the Blackwater mercenary firm, or its use of legal-spatial black holes like the 'extraordinary rendition' of untried terrorist suspects to foreign soil for interrogation, torture and indefinite imprisonment. (13)

As Chari and Verdery claim, postcolonial and postsocialist scholarship could provide mutually useful information on such imperial (empire-generating and sustaining) mechanisms as capital accumulation and nationalisms. But, in order to do so, scholars need to revisit ideologies and disciplinary frameworks that partitioned space into "three worlds", according to which postcolonialism is associated with the third world and postsocialism with the second (18). This focus on deconstructing the traditional three worlds division of the Cold War is at the basis of the second area that the authors identify as key to the creation of a platform of shared intellectual pursuit.

They propose to reject spatial partitions and argue for a single analytical field, "the (post-) Cold War", through which to analyse "how Cold War representations have shaped and continue to shape theory and politics" worldwide (18). Such an analytic framework, according to them, dismantles the traditional divide between third world postcolonial studies and second world postsocialist studies and enables an open-minded exploration of the effects of the Cold War ideology worldwide. (19). For example, both postcolonial and postsocialist scholarship productively critiques modernization theory, which for postsocialism was embodied by late-20th-century "transitology" and for postcolonial scholarship in the concept of development. Instituting the post-Cold War framework, the authors argue, would support scholarly search for comparisons and connections between different forms of imperialism, which have existed in different times in history and in different geographic locations. Ultimately, an understanding of their functioning would help us better comprehend contemporary forms of global capitalism.

As the third area of commonality, Chari and Verdery propose that a shared platform of knowledge of postsocialism and postcolonialism should be built on research of the governmental practices of state-sanctioned racism - the processes of racializing internal and external enemies by both socialist and colonial states. They argue that postcolonial and postcommunist scholarship should share knowledge on such racialized biopower both in its standard uses of racial classification, but also in the racializing of subjects by categories of class. In conclusion, the authors claim that the time has come to "liberate the Cold War from the ghetto of Soviet area studies and postcolonial thought from the ghetto of third world and colonial studies". Instead, they suggest a "liberatory path" to "jettison our two posts in favor of a single overarching one: the post-Cold War" (29).

In an introduction to a recent special issue of the Anthropology of East Europe Review, Narcis Tulbure reflects on the rising number of comparisons that anthropologists of postsocialism in east-central Europe make to postcolonial studies and argues that this is due to the "diminishing explanatory power of earlier theoretical models" that have "stimulated anthropologists of Eastern Europe to look for alternative conceptual developments or for models based on trans-regional comparisons" (6). In his review, he identifies several areas in which comparisons between postcolonialism and postsocialism are potentially most fruitful, including: rethinking the past and present projects of Europeanization through post-colonial theories; developing an anthropology of global socialism(s), which 
would extend the studies of postsocialisms beyond Europe; studying the political constitution of "the west" through the integration of postsocialist and postcolonial thought; and, ultimately, reinventing anthropology as a study of global processes.

A straightforward example of a comparison between postsocialism and postcolonialism is offered by David Kideckel in the same volume. Based on his fieldwork in Romania and India, he compares postsocialist and postcolonial realities by focusing on different activist practices as they relate to citizenship conceptions and discourses. In India, he observes, protests use the discourse of human rights, draw on larger social coalitions, and aim at challenging the system as such. Romanian protests that he observed, on the other hand, were grievance-based, fragmented and aiming at short term bargains. But despite these differences, Kideckel (following Jean and John Comaroff) identifies a crucial point of convergence - the ultimate audience of their protests is beyond state borders - offshore from the state, because it is the effects of globalization and neo-liberal penetration that animate these campaigns (117). At the conclusion to his article, Kideckel goes so far as to predict the future based on the different historical predicaments of colonialism and socialism, suggesting that the deepening crisis of capitalism will produce different effects on the two forms of social protest: "Postsocialist states, rejecting their past, top-down collectivities, will become more wedded to the global system while postcolonials, reminded of their past subalternity, reject it even further" (127).

\section{Conclusion}

Using the example of recent anthropological writing, I have tried to show how the concepts of postsocialism and postcolonialism are currently brought into conversation by anthropologists of postcommunist east-central Europe. Such efforts, I argue, are important and relevant responses to the changing political, economic and social geographies of power in the post-Cold War global world, which no longer follow state borders and generate new divisions within societies. However, I have also called attention to the divergent epistemological provenance of the two concepts, which may help explain the current popularity of postcolonial thought among scholars of postcommunist Europe and the relatively small interest in postsocialism among postcolonial intellectuals. While postcolonialism was born as a project of indigenous epistemological critique of the persistence of colonialism in the postcolonial present and contained clear liberatory desires, postsocialism was developed as an analytical tool by western scholars to analyse the societies of the former communist bloc. As I have tried to illustrate by reviewing a recent debate between central European and western scholars, this hegemonic epistemology of postsocialism raises questions concerning its usefulness as an intellectually empowering tool for scholars in challenging local inequities arising from the effects of global capitalism. One can only hope that, drawing on the historical richness of local intellectual traditions, scholars in east-central Europe will adopt the liberatory aspirations of postcolonial theory to develop forms of research and writing similarly inspired by a vision of social justice and engaged scholarship.

\section{Note}

1. The debate between Buchowski and Hann that I review here is a more recent and nuanced example of an argument between western and central European anthropologists about the former's orientalizing practices. An earlier (and much more heated) quarrel between the Polish anthropologist Leszek Dziegiel and the American anthropologists David Kideckel and Joel 
Halpern appeared in The Anthropology of East Europe Review during 1987-88 while the communist regimes in east-central Europe were still in power.

\section{Notes on contributor}

Hana Cervinkova was born in the Czech Republic and studied Social and Cultural Anthropology in the US (1997 BA Temple University, 2004 PhD New School for Social Research, New York City). Her initial work was based on an extended field research in the Czech Air Force (2001-02) in which she focused on the military's transformation following the Czech Republic's accession to NATO. In Playing Soldiers in Bohemia: An Ethnography of NATO Membership (2006), she studies the intersection of masculinity and national imagining in the transforming geopolitical context of the postsocialist Czech state. In 2003, she moved to Poland where she teaches anthropology and directs the International Institute for the Study of Culture and Education (IISCE) at the University of Lower Silesia (Dolnośląska Szkoła Wyższa). In her current writing as well as international educational work she explores ways of building critical democratic citizenship among youth through participatory action research and engaged ethnographic practice.

\section{Works cited}

Berdahl, Daphne, Matti Bunzl, and Martha Lampland. Altering States: Ethnographies of Transition in Eastern Europe and the Former Soviet Union. Ann Arbor: U of Michigan P, 2000.

Bhabha, Homi. Nation and Narration. London and New York: Routledge, 1990.

Bhabha, Homi. The Location of Culture. London and New York: Routledge, 1994.

Buchowski, Michał. "Hierarchies of Knowledge in Central-Eastern European Anthropology." Anthropology of East Europe Review 22.2 (2004): 5-14.

Buchowski, Michał. "Correspondence: Reply to Chris Hann." Anthropology of East Europe Review 23.1 (2005): 198-200.

Burawoy, Michael. "Afterword." Uncertain Transition: Ethnographies of Change in the Postsocialist World. Ed. Michael Burawoy and Katherine Verdery. Oxford: Rowman \& Littlefield, 1999.

Burawoy, Michael, and Katherine Verdery, ed. Uncertain Transition: Ethnographies of Change in the Postsocialist World. Oxford: Rowman \& Littlefield, 1999.

Cervinkova, Hana. Playing Soldiers in Bohemia: An Ethnography of NATO Membership. Prague: Set Out, 2006.

Cervinkova, Hana. "Migs and Cadres on the Move: Thoughts on the Mimetic Dimensions of Postsocialism." Kürti and Skalník 76-94.

Chari, Sharad, and Katherine Verdery. "Thinking between the Posts: Postcolonialism, Postsocialism, and Ethnography after the Cold War." Comparative Studies in Society and History 51.1 (2009): 6-34.

Comaroff, Jean, and John L. Comaroff. "Naturing the Nation: Aliens, Apocalypse and the Postcolonial State." Journal of Southern Africa Studies 27.3 (2001): 627-51.

Dziegiel, Leszek. "An East European View of American Anthropology in Eastern Europe." Anthropology of East Europe Review 6.1-2 (1987): 2-17.

Hann, Chris, ed. Postsocialism: Ideals, Ideologies, Practices. London and New York: Routledge, 2002.

Hann, Chris. "Correspondence: Reply to Michał Buchowski." Anthropology of East Europe Review 23.1 (2005): 194-7.

Kideckel, David, and Joel Halpern. "An American Perspective on a Polish View of American Anthropologists in Eastern Europe: Response to Leszek Dziegiel." Anthropology of East Europe Review 7.1-2 (1988): 14-25.

Kideckel, David. "Citizenship Discourse, Globalization, and Protest: A Postsocialist-Postcolonial Comparison." Anthropology of East Europe Review 27.2 (2009): 117-33.

Kürti, László, and Petr Skalník, ed. Postsocialist Europe: Anthropological Perspectives from Home. New York and Oxford: Berghahn, 2009.

Mbembe, Achille. On the Postcolony. Berkeley and Los Angeles: U of California P, 2001.

Said, Edward. Orientalism. New York: Pantheon, 1978.

Skalník, Petr, ed. A Post-Communist Millennium: The Struggles for Sociocultural Anthropology in Central and Eastern Europe. Prague: Set Out, 2002.

Spivak, Gayatri. In Other Wor(l)ds: Essays on Cultural Politics. New York: Methuen, 1987. 
Tulbure, Narcis. "Introduction to Special Issue: Global Socialisms and Postsocialisms." Anthropology of East Europe Review 27.2 (2009): 2-18.

Verdery, Katherine. What Was Socialism, and What Comes Next? Princeton: Princeton UP, 1996.

Wolfe, Thomas. "Cultures and Communities in the Anthropology of Eastern Europe and the Former Soviet Union." Annual Review of Anthropology 29 (2000): 195-216.

Wolff, Larry. Inventing Eastern Europe: The Map of Civilization on the Mind of the Enlightenment. Stanford: Stanford UP, 1994. 